\title{
Why Compensating the 'Stayers' for the Costs of Mobility Is the Wrong Way to Go
}

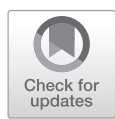

\author{
Julia Hermann
}

Like most of the previous respondents, I agree with Ferrera that the unequal division of the costs and benefits of free movement calls for action. My main criticism concerns his proposal to compensate non-mobile citizens. In my response, I shall expand on Christian Joppke's critique of Ferrera's presumption that 'moving' causes harm that 'stayers' should be indemnified for.

Ferrera argues that one way of strengthening the integrative capacity of EU citizenship would be to compensate those EU citizens who do not make use of their right to free movement for the negative effects of intra-EU mobility, and to empower them through particular initiatives. Joppke takes this to be a non-starter, because by making such a proposal, Ferrera confirms the populist portray of migrants as perpetrators and natives as victims and 'buys into the populists' hideous re-labelling of mobile EU citizens as "immigrants". I agree with the direction of this criticism, but not with Joppke's apparent denial of the existence of real adverse effects of freedom of movement. A crucial question is to what extent the perceived negative externalities are real. Ferrera is fully aware of the fact that some of the fears are ungrounded, and Joppke rightly criticises him for not addressing this when he makes his proposals for compensating and empowering non-mobile citizens. However, Joppke seems to presume that there are no negative externalities at all, thereby ignoring the point emphasised by Ferrera that despite the fact that, in the aggregate, mobility tends to benefit the receiving member states, there are also adverse effects, which are felt at the local level. We have to identify the real adverse effects in order to get a clearer picture of those perceptions of negative effects that are false, and must then ask what can and ought to be done to change these false perceptions.

Ferrera notes that in a particular territorial area, economic sector or policy field, the negative economic and social externalities (e.g. a decrease in available jobs, hospital beds, emergency care, social housing, school places etc.) may exceed the positive ones. He presents the negative externalities as 'produced by the mobiles'. Vandenbroucke and Sindbjerg Martinsen address 'social dumping'. Vandenbroucke moreover mentions the possibility that 
the negative externalities may be more real for countries of mass emigration than for countries of immigration. Independently of the answer to that question, it is important to address the fact that mobility can place a big burden on the former countries. Take a country such as Italy, where many welleducated young people emigrate in order to work in Britain, Germany, The Netherlands, etc. (brain drain). Would compensating, for instance, nonmobile Italian citizens be the adequate response to the brain drain that the country experiences? No. The adequate response would be to make the reforms necessary for making it attractive for talented young Italians to stay in their country, and for attracting talented citizens of other member states.

The proposal to compensate non-mobile citizens is problematic for a number of reasons. First, it gains support from the view that the mobiles produce the negative externalities, which is not correct. They are produced by the system, i.e., they are the consequences of giving people the right to free movement without providing mechanisms that prevent a race to the bottom of welfare services, wage dumping and so forth. Once we abandon the picture of movers producing negative externalities, Ferrera's proposal becomes much less plausible. Second, every EU citizen is a potential mover. Someone who is a stayer today might be a mover tomorrow. Every EU citizen has the formal freedom of movement. At any point in time, this is not a substantial freedom for many people, but this situation is not static. Not only is it possible that stayers may want to exercise their freedom of movement in the future, it is also possible that they get into a situation where they find themselves compelled to do so. Third, the demand for compensation doesn't fit well with Ferrera's claim that one of the corresponding duties of the right to free-movement is "to bear the burdens of "hospitality". Fourth, the demand makes negative externalities seem unavoidable, which is not the case. Fifth, although the burdens are not shared equally, mobility ultimately affects society as a whole when it leads to a decline of domestic cohesion. In the long run, the burdens are not felt merely locally, but globally. Finally, compensatory measures don't go far enough. We have to address the systemic flaws, the origins of the European malaise.

The costs of mobility call for two things: a justification to those bearing them disproportionately, and measures to reduce them. Those who lose out are entitled to a justification for why they ought to support freedom of movement (see Sangiovanni's contribution to this debate). It might well be that such a justification is currently not available, because if we consider the situation of EU citizens on the whole, the costs of free movement might be disproportionately high. There seems to be an agreement between most of the respondents in this forum that the required justification would be avail- 
able if the social dimension of the EU were strengthened significantly, implying that, as things are now, many EU citizens are entirely justified in opposing freedom of movement.

Given the present form of the EU, some of the negative effects might indeed be unavoidable. Due to big differences between member states concerning minimum wage regulations, access to social protection, flexibility of the labour market, taxes etc., mobility of workers leads to a race to the bottom. As Vandenbroucke writes, 'if we don't want immigration to boost a precarious, hyper-flexible segment of labour markets, there should be limits to precariousness and flexibility across the board'. Vandenbroucke claims that the only way to tackle the distributive risks associated with mobility is to be more demanding with regard to the quality of welfare states. He asks for common principles, e.g. 'All workers are covered by minimum wage regulation'. Seeleib-Kaiser argues that the relevant regulation (in the form of national and EU minimum standards in labour and social law) is already there but needs to be enforced. At this point the question becomes whether the EU is, in its current state, able to enforce it. Vandenbroucke admits that 'developing and translating such principles into tangible realities is an uphill battle in today's Europe', but emphasises that 'there is no alternative if free movement is to be reconciled with domestic cohesion'. Ferrera proposes to establish a supranational scheme providing homogeneous protections to mobile workers. Sangiovanni stresses that justice requires a much broader social union than we currently have. He suggests grounding Ferrera's proposals in his conception of justice for the European Union.

There are doubts as to whether the EU as we know it is capable of achieving the political union necessary for broadening the social union. Because the EU is, in the first instance, an economic union - the project of a common market - and because of its well-known democratic deficit, a broader social union might only be reachable via fundamental reforms. Perhaps we even need to start all over again. Ferrera may be right that 'incrementalism is the only policy strategy for the EU today', but this may mean that our problem is not solvable by any of the policy strategies that are available to the EU in its current form. One rather radical proposal is to create a European Republic, in which there are no nation-states anymore, but only regions, cities, and most importantly - citizens. ${ }^{1}$ I do not wish to defend this utopia here, but want to emphasise that there is the real possibility that in its current form,

\footnotetext{
Guérot, U. (2017), Warum Europa eine Republik werden muss! Eine politische Utopie [Why Europe Needs to Become a Republic! A Political Utopia], third edition. Bonn: Dietz.
} 
the EU cannot achieve the required social union. This would mean that due to the internal constitution of the EU, EU citizenship couldn't fulfil its integrative functions. If we follow Ulrike Guérot, citizenship that fosters integration and solidarity has to imply equality in front of the law, equal general voting rights and equal social participatory rights. ${ }^{2}$ In today's EU, citizens do not have any of this. Unfortunately, this is not stuff that could simply be added to the 'EU citizenship container'. I am not saying that this is the correct diagnosis. My point is that given the enormous problems the EU is facing, we have to take this possibility very seriously.

Open Access This chapter is licensed under the terms of the Creative Commons Attribution 4.0 International License (http://creativecommons.org/licenses/by/4.0/), which permits use, sharing, adaptation, distribution and reproduction in any medium or format, as long as you give appropriate credit to the original author(s) and the source, provide a link to the Creative Commons license and indicate if changes were made.

The images or other third party material in this chapter are included in the chapter's Creative Commons license, unless indicated otherwise in a credit line to the material. If material is not included in the chapter's Creative Commons license and your intended use is not permitted by statutory regulation or exceeds the permitted use, you will need to obtain permission directly from the copyright holder.

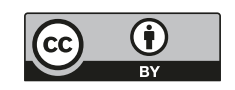

2 Guérot, U. (2017), see above. 